Tersedia online di: http://ejournal-balitbang.kkp.go.id/index.php/bawal
e-mail:bawal.puslitbangkan@ gmail.com
BAWAL WIDYA RISET PERIKANAN TANGKAP
Volume 10 Nomor 1 April 2018
p-ISSN: 1907-8226
e-ISSN: 2502-6410
BAWAL
Nomor Akreditasi: 620/AU2/P2MI-LIPI/03/2015

\title{
PENILAIAN KONDISI EKOLOGI PERAIRAN UNTUK PENGEMBANGAN BUDIDAYA KERANG HIJAU (Perna viridis L.) DI PERAIRAN KUALA LANGSA, ACEH
}

\section{ASSESSMENT OF WATERS ECOLOGY CONDITION FOR THE DEVELOPMENT OF GREEN MUSSEL CULTIVATION (Perna viridis L.) IN THE COASTAL OF KUALA LANGSA WATERS, ACEH}

\author{
Andi Sagita*1, Rahmat Kurnia $^{1}$ dan Sulistiono $^{1}$ \\ ${ }^{1}$ Departemen Manajemen Sumberdaya Perairan, Institut Pertanian Bogor, Jl. Agatis, Bogor 16680, Jawa Barat, Indonesia \\ Teregistrasi I tanggal: 29 Mei 2017; Diterima setelah perbaikan tanggal: 12 Februari 2018; \\ Disetujui terbit tanggal: 13 Februari 2018
}

\begin{abstract}
ABSTRAK
Penelitian ini bertujuan untuk menilai kondisi ekologi untuk pengembangan budidaya kerang hijau di Kuala Langsa, Aceh. Data ekologi perairan dikumpulkan di 12 titik sampling pada Agustus, September dan Oktober 2016 untuk mewakili musim hujan, serta Maret, April dan Mei 2017 untuk mewakili musim kemarau. Data dianalisis dengan analisis komponen utama (principal component analysis/PCA). Suhu perairan Kuala Langsa berkisar $25,5-35,6^{\circ} \mathrm{C}$ dengan rata-rata $30,5 \pm 1,7^{\circ} \mathrm{C}$; salinitas $25,9-34,0$ ppt dengan rata-rata $29,9 \pm 1,3^{\circ} \mathrm{C}$; $\mathrm{pH} 7,0-9,2$ dengan rata-rata $8,1 \pm 0,3$; oksigen terlarut 3,9-6,8 $\mathrm{mg} / \mathrm{l}$ dengan rata-rata 5,5 $\pm 0,5 \mathrm{mg} / \mathrm{l}$; kecepatan arus berkisar $0,1-0,9 \mathrm{~m} / \mathrm{s}$ dengan rata-rata $0,3 \pm 0,1 \mathrm{~m} / \mathrm{s}$; serta kelimpahan fitoplankton berkisar $1,32 \times 10^{5} \mathrm{sel} /$ $\mathrm{m}^{3}$ hingga $6,86 \times 10^{5} \mathrm{sel} / \mathrm{m}^{3}$ dengan rata-rata $3,88 \times 10^{5} \pm 1,08 \times 10^{5} \mathrm{sel} / \mathrm{m}^{3}$. PCA yang diaplikasikan pada seluruh data menghasilkan dua komponen utama, yaitu PC1 dan PC2 dengan nilai akar ciri (eigenvalue) sebesar 2,096 dan 1,770; dimana PC1 secara kumulatif dapat menjelaskan ragam seluruh data sebesar 34,9\% yang dibangun oleh parameter salinitas, suhu dan plankton, sedangkan PC2 sebesar 64,4\% yang dibangun oleh parameter oksigen terlarut dan salinitas. Berdasarkan analisis dengan membandingkan parameter ekologi perairan untuk budidaya kerang hijau berdasarkan literatur maka dapat disimpulkan bahwa kondisi ekologi perairan pada musim hujan dan kemarau dapat mendukung pengembangan budidaya kerang hijau di Kuala Langsa, Aceh.
\end{abstract}

Kata Kunci: Budidaya kerang hijau; ekologi; Kuala Langsa; penilaian

\section{ABSTRACT}

The research aims to assess the waters ecology condition for the development of green mussel cultivation in the coastal of Kuala Langsa, Aceh. Parameters of waters ecology collected at 12 sampling points in August, September and October 2016 to represent the rainy season, while March, April and May 2017 to represent the dry season. Principal component analysis (PCA) used to assess the waters ecology. The temperature ranged $25.5-35.6{ }^{\circ} \mathrm{C}$ average by $30.5 \pm 1.7^{\circ} \mathrm{C}$; salinity by $25.9-34.0$ ppt average by $29.9 \pm 1.3{ }^{\circ} \mathrm{C}$; $\mathrm{pH}$ by $7.0-9.2$ average by $8.1 \pm 0.3$; dissolved oxygen from $3.9-6.8$ average by $5.5 \pm 0.5 \mathrm{mg} / \mathrm{l}$; current velocity by $0.1-0.9$ $\mathrm{m} / \mathrm{s}$ average by $0.3 \pm 0.1 \mathrm{~m} / \mathrm{s}$; and abundance of phytoplankton ranged $1.32 \times 10^{5} \mathrm{cell} / \mathrm{m}^{3}$ to $6.86 \times 10^{5} \mathrm{cell} / \mathrm{m}^{3}$. Two principal component was PC1 and PC2 with a eigenvalue of 2.096 and 1.770 extracted from PCA; where $P C 1$ on cumulatively can explain $34.9 \%$ of all data collected, mainly contributed by parameters of salinity, temperature and plankton, while PC2 was $64.4 \%$ contributed by parameters dissolved oxygen and salinity. Based on the analysis by comparing waters ecology parameters for green mussel culture based from literate study, it suggests that the waters ecology condition could support the development of green mussel culture in the coastal of Kuala Langsa, Aceh.

Keywords: Green mussel culture; ecology; Kuala Langsa; assessment 


\section{PENDAHULUAN}

Kerang hijau merupakan famili Mytilidae yang mudah untuk dibudidayakan atau dapat dikumpulkan di wilayah pesisir serta dapat menyediakan sumber nutrisi yang penting bagi makanan manusia (FAO, 2006; Fuentes et al., 2009). Spesies ini juga dikenal dengan karakteristik laju pertumbuhan yang cepat dan memiliki toleransi terhadap perubahan berbagai kondisi lingkungan serta dapat dibudidayakan dengan metode yang sederhana (Sallih, 2005). Budidaya kerang hijau saat ini terus berkembang karena dapat memberikan dampak ekonomi bagi masyarakat pesisir, selain itu budidaya biota ini dapat dilakukan dengan biaya produksi yang rendah namun menghasilkan profitabilitas yang tinggi (Kripa \& Mohamed, 2008; Acosta et al., 2009). Budidaya kerang hijau juga tergolong budidaya yang ramah lingkungan (Shumway et al., 2003), karena tidak berdampak terhadap penurunan kualitas lingkungan (Ellis et al., 2002), sehingga dapat dilakukan secara berkelanjutan (CostaPierce, 2008).

Penilaian terhadap parameter ekologi perairan untuk pengembangan budidaya perikanan sangat diperlukan, hal tersebut berguna untuk menghasilkan estimasi kondisi kualitas perairan secara representatif dan komprehensif (Butler et al., 2001). Parameter-parameter lingkungan perairan yang sesuai akan berpengaruh bagi pertumbuhan kerang hijau seperti kedalaman, suhu air, salinitas dan kandungan oksigen (Radiarta et al., 2011). Selain itu parameter lingkungan seperti turbiditas, arus, salinitas dan suhu umumnya paling penting dalam pemilihan lokasi budidaya karena telah terbukti mempengaruhi laju pertumbuhan kerang hijau (Soon \& Ransangan, 2014). Penentuan lokasi budidaya untuk budidaya kerang hijau juga perlu memperhatikan kelimpahan makanan serta ada tidaknya predator maupun organisme penganggu lainnya (Valavanis, 2002; Laxmilatha, 2013).

Kegiatan pengambilan kerang hijau di perairan Kuala Langsa telah dilakukan masyarakat setempat baik menggunakan alat, seperti garuk maupun dengan mengumpulkan langsung tanpa alat. Kerang hijau yang terdapat di perairan Kuala Langsa mengindikasikan bahwa kerang hijau tersebut dapat hidup dan berkembang pada perairan Kuala Langsa. Pertimbangan-pertimbangan tersebut yang menjadi asumsi bahwa biota kerang hijau yang selama ini menjadi salah satu komoditas tangkapan di perairan Kuala Langsa memiliki potensi untuk dikembangkan dalam suatu sistem budidaya. Berdasarkan hasil observasi, perairan Kuala Langsa juga mempunyai kedalaman yang sesuai untuk kegiatan budidaya laut khususnya kerang hijau yaitu berkisar $2 \mathrm{~m}$ hingga $7 \mathrm{~m}$ dengan substrat pasir berlumpur dan daerah tersebut juga tergolong terlindung dari faktor oseanografi karena berbatasan langsung dengan Selat Malaka.

Berdasarkan uraian tersebut diatas, maka hipotesis yang coba dibangun dalam penelitian ini adalah bahwa kondisi ekologi perairan akan sesuai untuk pengembangan budidaya kerang hijau di Kuala Langsa. Keberhasilan budidaya kerang hijau tersebut sangat didukung oleh kondisi lingkungan yang ideal sehingga aktivitas budidaya dapat dilakukan secara optimal. Namun, perlu dilakukan penilaian untuk mengetahui karakteristik dan mengevaluasi kondisi ekologi perairan Kuala Langsa berdasarkan variasi waktu (temporal) dan ruang (spasial). Penelitian ini bertujuan untuk menilai kondisi ekologi perairan untuk pengembangan budidaya kerang hijau di Kuala Langsa, Aceh.

\section{BAHANDANMETODE}

Wilayah Kota Langsa terdapat dua musim yang berbeda yaitu musim hujan yang terjadi antara September - Februari dan musim kemarau terjadi pada Maret Agustus (BPS Kota Langsa, 2015). Pengumpulan data ekologi perairan pada musim hujan dilakukan pada Agustus, September dan Oktober 2016, sedangkan musim kemarau dilakukan pada Maret, April dan Mei 2017. Pengumpulan data dilakukan selama 3 bulan atau 12 minggu pada setiap musim, sampling tersebut dianggap sudah dapat mewakili perbedaan kondisi ekologi perairan Kuala Langsa pada musim hujan dan musim kemarau.

Pengumpulan data parameter ekologi perairan dilakukan pada 12 titik sampling dengan jarak dari masingmasing titik sampling adalah $\pm 20 \mathrm{~m}$ (Gambar 1). Parameter ekologi perairan tersebut diukur secara in situ pada kedalaman antara $0-3$, dengan pertimbangan kedalaman perairan yang direkomendasikan untuk budidaya kerang hijau. Data ekologi perairan yang diukur meliputi suhu perairan, $\mathrm{pH}$, salinitas dan oksigen terlarut menggunakan alat Water Quality Checker (WQC), sedangkan pengukuran kecepatan arus menggunakan current meter. Sampling dilakukan seminggu sekali pada pagi (08.00), siang (13.00) dan sore (16.00) hari selama periode penelitian. 


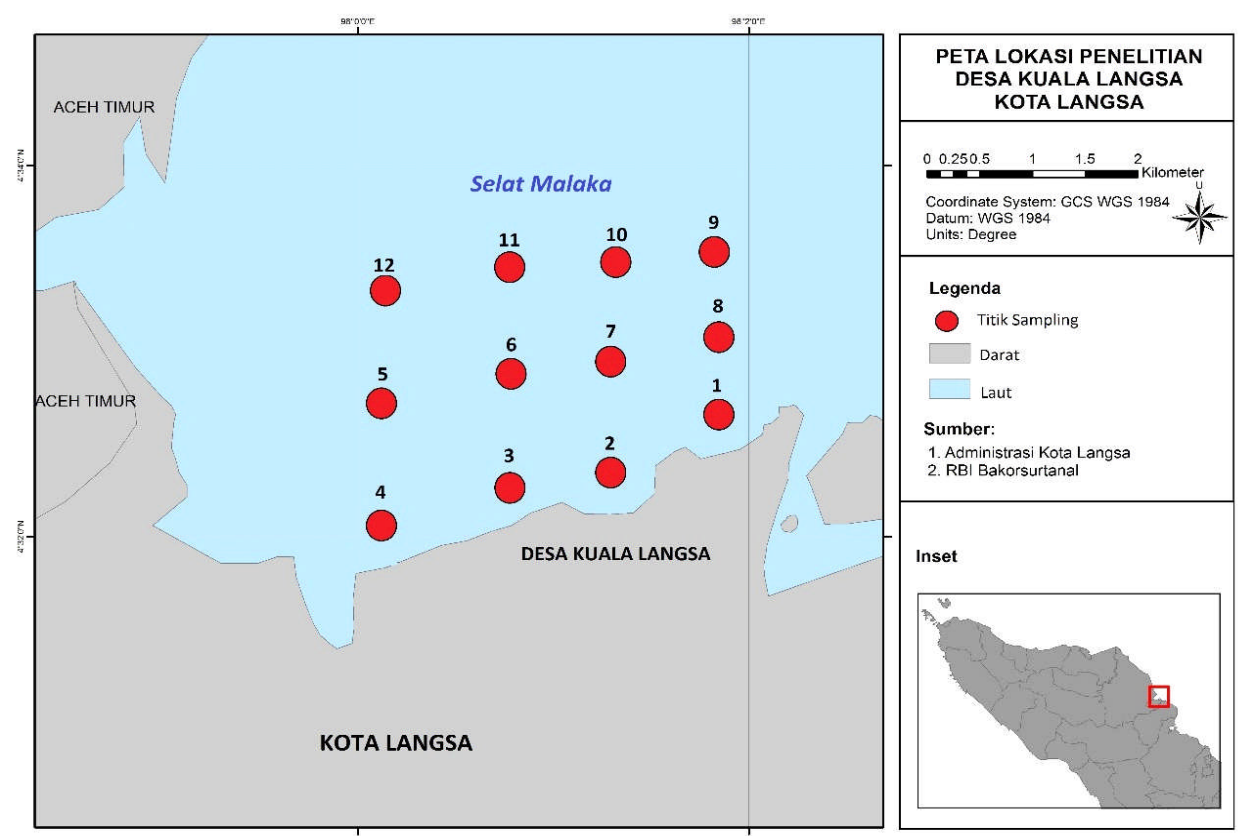

Gambar 1. Titik sampling parameter ekologi perairan di pesisir Kuala Langsa, Aceh.

Figure 1. Sampling points of waters ecology parameters in costal Kuala Langsa, Aceh.

Pengambilan contoh fitoplankton pada setiap titik sampling juga dilakukan dalam penelitian ini, sehingga dapat memberikan gambaran mengenai kondisi biologi perairan Kuala Langsa. Pengambilan sampel fitoplankton dilakukan secara kuantitatif untuk mengetahui kepadatan fitoplankton per satuan volume. Pengumpulan fitoplankton dilakukan dengan menyaring air sebanyak satu liter menjadi $100 \mathrm{ml}$ yang disimpan dalam botol sampel. Sampel diambil dari permukaan air dengan menggunakan plankton net mesh size 50. Sampel kemudian diawetkan dengan larutan formalin konsentrasi $4 \%$, kemudian dihitung kelimpahannya menggunakan sedgewick-rafter counting method dengan teknik sapuan dan diperoleh adalah satuan sel.m $\mathrm{m}^{-3}$ (Blakar, 1978).

Data parameter ekologi perairan yang terkumpul, kemudian dianalisis dengan analisis komponen utama atau Principal Component Analysis (PCA) menggunakan perangkat lunak Minitab 16. Analisis komponen utama digunakan untuk interpretasi kumpulan data dengan multi parameter yang diperoleh dari hasil pengukuran parameter ekologi perairan, sehingga memudahkan dalam menyederhanakan kompleksitas data dan mengekstrak informasi. Analisis komponen utama juga akan mengubah parameter asli ke parameter baru yang tidak berkolerasi yaitu berupa kombinasi linear dari parameter-parameter asli. PCA adalah satu teknik statistik multivariat yang secara linear mengubah bentuk sekumpulan variabel asli menjadi kumpulan yang lebih kecil dan tidak berkolerasi yang dapat mewakili kumpulan variabel aslinya (Shrestha \& Kazama, 2007; Iscen et al., 2008). Data kondisi ekologi perairan juga dianalisis secara deskriptif kuantitatif dan kualitatif meliputi nilai minimal dan maksimal, rata-rata serta standar deviasi, dimana analisis ini dilakukan untuk memperoleh gambaran umum tentang kondisi perairan Kuala Langsa.

\section{HASIL DAN BAHASAN Hasil}

Kondisi ekologi perairan Kuala Langsa cenderung stabil selama periode penelitian. Suhu rata-rata terendah terjadi pada Agustus dengan rata-rata $29,6 \pm 1,4^{\circ} \mathrm{C}$; dan suhu tertinggi terjadi pada Maret dengan rata-rata 31,3 \pm $1,6^{\circ} \mathrm{C}$; sedangkan salinitas terendah terjadi pada Agustus dengan rata-rata $29,3 \pm 1,1 \mathrm{ppt}$ dan salinitas tertinggi pada Maret ppt dengan rata-rata 30,5 $\pm 1,1 \mathrm{ppt}$. Nilai $\mathrm{pH}$ terendah terjadi pada Oktober dan Mei dengan rata-rata sama yaitu 8,0 $\pm 0,2 \mathrm{ppt}$, sedangkan rata-rata oksigen terlarut selama periode penelitian tercatat nilai DO cenderung stabil dengan kisaran 3,9-6,8 mg/l. Kecepatan arus selama periode penelitian berkisar $0,1-0,9 \mathrm{~m} / \mathrm{s}$, dimana arus tertinggi terjadi pada Agustus, Oktober, April dan Mei dengan rata-rata 0,3 $\pm 0,1 \mathrm{~m} / \mathrm{s}$. Kelimpahan fitoplankton tertinggi terjadi pada Agustus dengan kelimpahan rata-rata $3,98 \times 10^{5} \pm 1,10 \times 10^{5} \mathrm{sel} / \mathrm{m}^{3}$; sedangkan kelimpahan rata-rata terendah terjadi pada Mei sebesar $3,72 \times 10^{5} \pm 1,11 \times 10^{5} \mathrm{sel} / \mathrm{m}^{3}$. Tabulasi data meliputi nilai rata-rata dan standar deviasi parameter ekologi selama periode penelitian berdasarkan bulan dan titik sampling di perairan Kuala Langsa tersaji pada Tabel 1 dan 2. 
Tabel 1. Parameter ekologi perairan selama periode penelitian berdasarkan titik sampling di pesisir Kuala Langsa, Aceh

Table 1. Waters ecology parameters during research period based on the sampling points in coastal Kuala Langsa, Aceh

\begin{tabular}{|c|c|c|c|c|c|c|}
\hline \multirow{2}{*}{$\begin{array}{c}\text { Titik } \\
\text { sampling/ } \\
\text { Sampling } \\
\text { points }\end{array}$} & \multicolumn{6}{|c|}{ Parameter / Parameters } \\
\hline & $\begin{array}{c}\text { Suhu / } \\
\text { Temperature } \\
\left({ }^{\circ} \mathrm{C}\right)\end{array}$ & $\begin{array}{l}\text { Salinitas / } \\
\text { Salinity } \\
\text { (ppt) }\end{array}$ & $\begin{array}{c}\text { pH / } \\
\text { Acidity }\end{array}$ & $\begin{array}{l}\text { Oksigen } \\
\text { terlarut / } \\
\text { Dissolved } \\
\text { oxygen } \\
(\mathrm{mg} / \mathrm{l})\end{array}$ & $\begin{array}{l}\text { Arus } \\
\text { /Current } \\
\text { velocity } \\
(\mathbf{m} / \mathbf{s})\end{array}$ & $\begin{array}{c}\text { Fitoplankton / } \\
\text { Fitoplankton } \\
\left(\text { x } 10^{5} \text { cell } / \mathbf{m}^{3}\right)\end{array}$ \\
\hline 1 & $30,4 \pm 1,8$ & $29,8 \pm 1,3$ & $8,2 \pm 0,3$ & $5,4 \pm 0,5$ & $0,3 \pm 0,1$ & $4,00 \pm 1,17$ \\
\hline 2 & $30,3 \pm 1,9$ & $29,9 \pm 1,3$ & $8,2 \pm 0,3$ & $5,5 \pm 0,5$ & $0,3 \pm 0,1$ & $4,04 \pm 1,09$ \\
\hline 3 & $30,5 \pm 1,8$ & $30,0 \pm 1,2$ & $8,1 \pm 0,3$ & $5,4 \pm 0,5$ & $0,3 \pm 0,1$ & $4,05 \pm 1,22$ \\
\hline 4 & $30,9 \pm 1,9$ & $30,1 \pm 1,4$ & $8,1 \pm 0,3$ & $5,5 \pm 0,5$ & $0,3 \pm 0,1$ & $3,82 \pm 1,12$ \\
\hline 5 & $30,3 \pm 1,7$ & $29,5 \pm 1,1$ & $8,2 \pm 0,3$ & $5,6 \pm 0,4$ & $0,3 \pm 0,1$ & $3,69 \pm 1,08$ \\
\hline 6 & $30,4 \pm 1,6$ & $29,8 \pm 1,2$ & $8,1 \pm 0,3$ & $5,6 \pm 0,4$ & $0,2 \pm 0,1$ & $3,86 \pm 1,10$ \\
\hline 7 & $30,6 \pm 1,7$ & $30,1 \pm 1,5$ & $8,1 \pm 0,2$ & $5,4 \pm 0,5$ & $0,2 \pm 0,1$ & $3,82 \pm 0,98$ \\
\hline 8 & $30,4 \pm 1,6$ & $29,9 \pm 1,2$ & $8,1 \pm 0,3$ & $5,4 \pm 0,5$ & $0,3 \pm 0,1$ & $3,82 \pm 1,04$ \\
\hline 9 & $30,5 \pm 1,7$ & $29,9 \pm 1,2$ & $8,1 \pm 0,3$ & $5,5 \pm 0,4$ & $0,3 \pm 0,1$ & $3,88 \pm 1,01$ \\
\hline 10 & $30,5 \pm 1,5$ & $30,3 \pm 1,6$ & $8,1 \pm 0,3$ & $5,6 \pm 0,4$ & $0,3 \pm 0,1$ & $3,98 \pm 1,11$ \\
\hline 11 & $30,2 \pm 1,4$ & $30,3 \pm 1,6$ & $8,1 \pm 0,3$ & $5,5 \pm 0,4$ & $0,3 \pm 0,1$ & $3,70 \pm 1,02$ \\
\hline 12 & $30,7 \pm 1,7$ & $30,1 \pm 1,5$ & $8,1 \pm 0,3$ & $5,5 \pm 0,4$ & $0,3 \pm 0,1$ & $3,85 \pm 1,04$ \\
\hline
\end{tabular}

Tabel 2. Parameter ekologi perairan selama periode penelitian berdasarkan bulan sampling di pesisir Kuala Langsa, Aceh

Table 2. Waters ecology parameters during research period based sampling time (month) in coastal Kuala Langsa, Aceh

\begin{tabular}{|c|c|c|c|c|c|c|}
\hline \multirow[t]{2}{*}{ Bulan / Month } & \multicolumn{6}{|c|}{ Parameter / Parameters } \\
\hline & $\begin{array}{c}\text { Suhu / } \\
\text { Temperature } \\
\left({ }^{\circ} \mathrm{C}\right)\end{array}$ & $\begin{array}{l}\text { Salinitas } \\
\text { / Salinity } \\
\quad \text { (ppt) }\end{array}$ & $\begin{array}{c}\text { pH / } \\
\text { Acidity }\end{array}$ & $\begin{array}{l}\text { Oksigen } \\
\text { terlarut / } \\
\text { Disolved } \\
\text { oxygen } \\
\text { (mg/l) }\end{array}$ & $\begin{array}{l}\text { Arus / } \\
\text { Current } \\
\text { velocity } \\
(\mathrm{m} / \mathrm{s})\end{array}$ & $\begin{array}{c}\text { Plankton / } \\
\text { Plankton } \\
\left(\text { x } 10^{5} \text { cell } / m^{3}\right)\end{array}$ \\
\hline Agustus / August & $29,8 \pm 1,2$ & $29,3 \pm 1,1$ & $8,3 \pm 0,4$ & $5,5 \pm 0,4$ & $0,3 \pm 0,1$ & $3,98 \pm 1,10$ \\
\hline September /September & $29,6 \pm 1,4$ & $29,5 \pm 0,8$ & $8,1 \pm 0,2$ & $5,6 \pm 0,3$ & $0,2 \pm 0,2$ & $3,93 \pm 1,04$ \\
\hline Oktober / October & $30,3 \pm 1,4$ & $29,7 \pm 0,8$ & $8,0 \pm 0,2$ & $5,6 \pm 0,6$ & $0,3 \pm 0,1$ & $3,83 \pm 1,05$ \\
\hline Maret / March & $31,3 \pm 1,6$ & $30,5 \pm 1,1$ & $8,1 \pm 0,4$ & $5,4 \pm 0,5$ & $0,2 \pm 0,1$ & $3,90 \pm 1,19$ \\
\hline April / April & $31,1 \pm 2,1$ & $30,2 \pm 1,7$ & $8,2 \pm 0,3$ & $5,5 \pm 0,5$ & $0,3 \pm 0,1$ & $3,87 \pm 1,07$ \\
\hline Mei / May & $30,9 \pm 1,7$ & $30,4 \pm 1,8$ & $8,0 \pm 0,2$ & $5,4 \pm 0,4$ & $0,3 \pm 0,1$ & $3,72 \pm 1,12$ \\
\hline
\end{tabular}

Principal Component Analysis (PCA) diaplikasikan pada seluruh data parameter ekologi perairan yaitu suhu, salinitas, $\mathrm{pH}$, oksigen terlarut, arus dan fitoplankton dari 12 titik sampling dengan tujuan untuk mengidentifikasi setiap parameter yang mempengaruhi lokasi penelitian. Hasil PCA menunjukkan bahwa terdapat 2 komponen utama yang dianggap dapat menggambarkan karakteristik perairan Kuala Langsa dengan nilai akar ciri atau Eigenvalue sebesar 2,096 dan 1,770 (Gambar 2). Menurut Shrestha \& Kazama (2007), nilai akar ciri memberikan ukuran tentang pentingnya komponen utama, dimana komponen utama dengan nilai akar ciri tertinggi adalah yang paling signifikan mewakili karakteristik perairan.
Pemilihan komponen utama berdasarkan nilai akar ciri (eigenvalue) yang lebih besar dari satu karena mengandung banyak informasi yang dapat dijelaskan keragaman dari variabel asli (Simeonov et al., 2003; Boyacioglu, 2006; Iscen et al., 2008).

Hasil analisis komponen utama menunjukkan bahwa terdapat 2 komponen utama yaitu PC 1 dan PC2 yang dianggap dapat menggambarkan karakteristik perairan Kuala Langsa untuk pengembangan budidaya kerang hijau, PC1 secara kumulatif dapat menjelaskan ragam seluruh data sebesar 34,9\%, sedangkan PC2 sebesar 64,4\% (Tabel 3). 


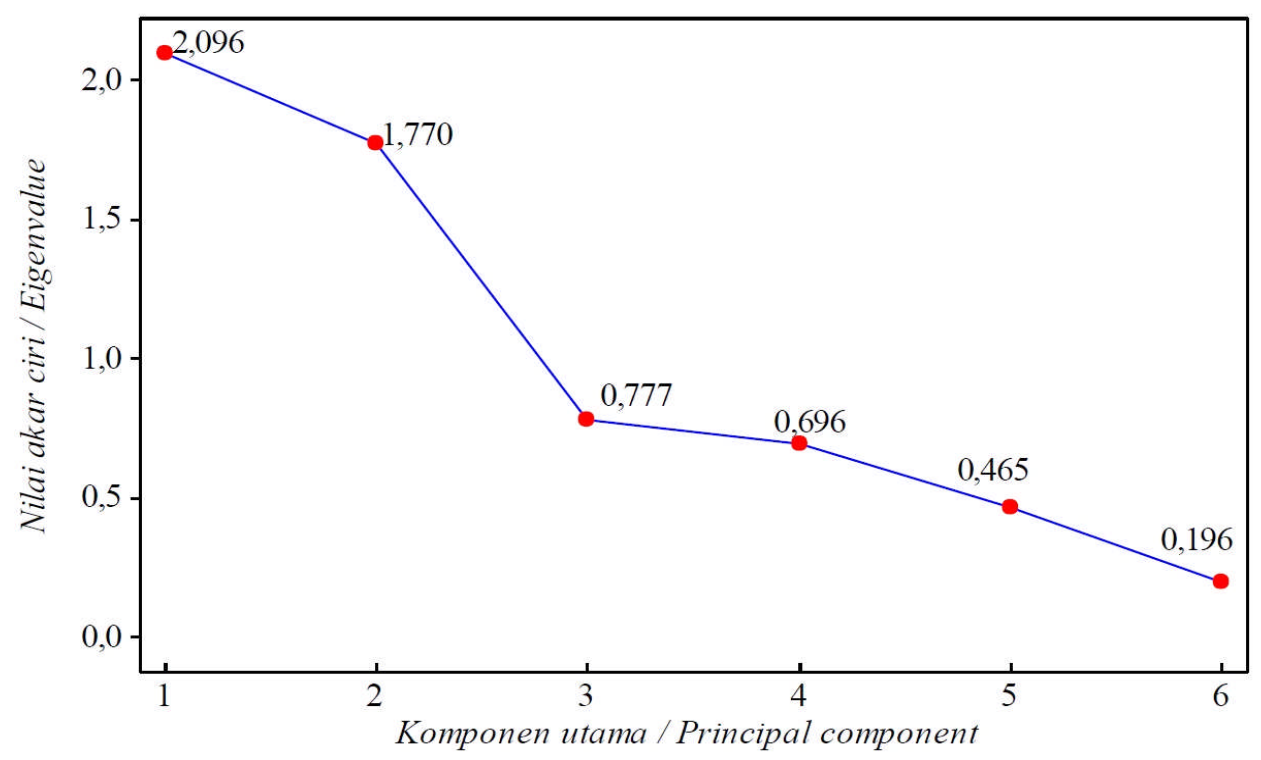

Gambar 2. Nilai akar ciri dari analisis komponen utama parameter ekologi perairan pesisir Kuala Langsa, Aceh.

Figure 2. Eigenvalue the principal component analysis coastal waters ecology parameters of Kuala Langsa, Aceh.

Tabel 3. Nilai akar ciri, proporsi dan kumulatif komponen utama terpilih untuk analisis parameter ekologi perairan pesisir Kuala Langsa, Aceh

Table 3. Eigenvalue, proportion and cumulative of principal component selected for analysis coastal waters ecology parameters of Kuala Langsa, Aceh

\begin{tabular}{lcr}
\hline \multicolumn{1}{c}{ Parameter / Parameters } & \multicolumn{2}{c}{ Komponen utama / } \\
& Principal component \\
\cline { 2 - 3 } & PC1 & PC2 \\
\hline Suhu / Temperature & 0,452 & $-0,072$ \\
Salinitas / Salinity & 0,590 & 0,035 \\
$\mathrm{pH} /$ Acidity & $-0,612$ & $-0,100$ \\
Oksigen terlarut / Dissolved oxygen & $-0,190$ & 0,574 \\
Arus / Current velocity & $-0,167$ & $-0,636$ \\
Plankton / Plankton & 0,095 & $-0,500$ \\
Nilai akar ciri / Eigenvalue & 2,096 & 1,770 \\
Proporsi / Proportion (\%) & 34,9 & 29,5 \\
Kumulatif / Cumulative (\%) & 34,9 & 64,4 \\
\hline
\end{tabular}

Analisis komponen utama juga dapat menjelaskan pula bahwa titik-titik sampling ( stasiun) yaitu karakter stasiun 1 dan 2 dibentuk bersama-sama parameter $\mathrm{pH}$ dan arus, kemudian karakter stasiun 3, 8 dan 12 dibentuk oleh parameter suhu dan plankton, selanjutnya stasiun 5, 6, dan 9 dibentuk oleh parameter oksigen terlarut (DO), serta stasiun 4, 7, dan 11 dibentuk bersama-sama oleh parameter salinitas (Gambar 3).

Perbandingan parameter ekologi perairan untuk pengembangan budidaya kerang hijau di Kuala Langsa berdasarkan beberapa literatur tersaji pada Tabel 4 . 


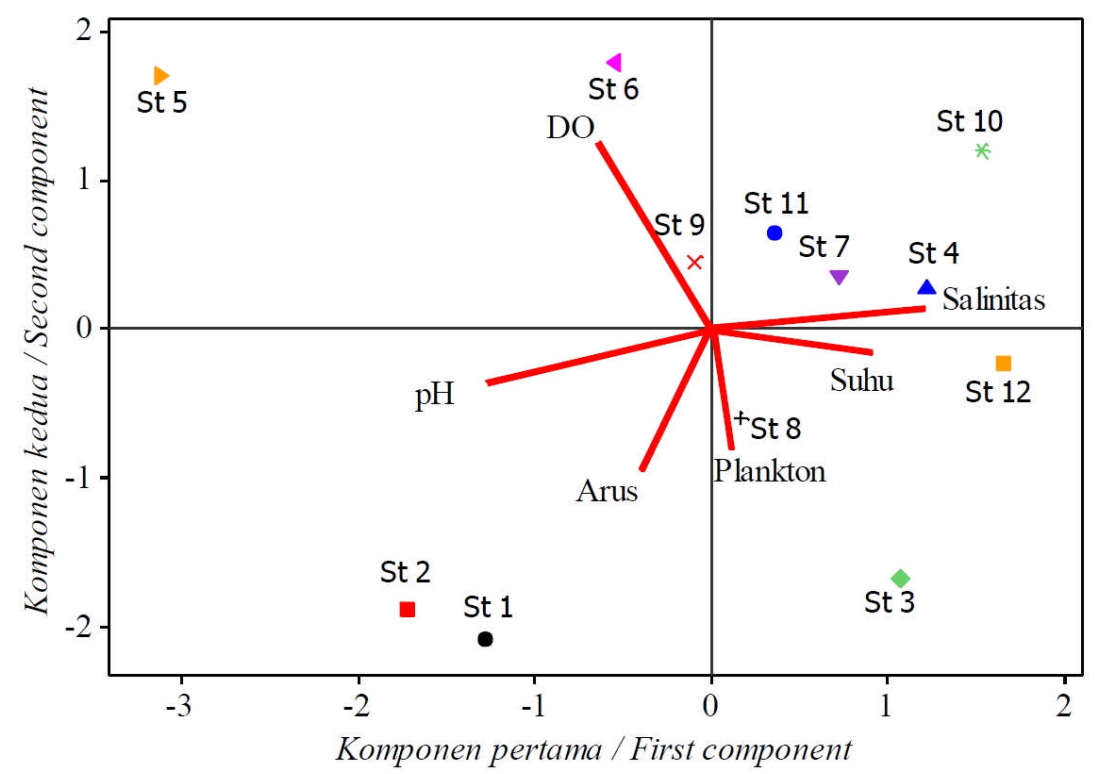

Gambar 3. Biplot hasil analisis komponen utama terhadap parameter ekologi perairan pesisir Kuala Langsa, Aceh.

Figure 3. Bilplot results of principal component analysis toward coastal waters ecology parameters of Kuala Langsa, Aceh.

Tabel 4. Parameter ekologi perairan untuk pengembangan budidaya kerang hijau

Table 4. Water ecology parameters for development of green mussel cultivation

\begin{tabular}{|c|c|c|c|c|c|}
\hline \multirow{2}{*}{$\begin{array}{l}\text { Parameter / } \\
\text { Parameters }\end{array}$} & \multirow{2}{*}{$\begin{array}{l}\text { Unit / } \\
\text { Unit }\end{array}$} & \multicolumn{2}{|c|}{$\begin{array}{c}\text { Pesisir Kuala Langsa / } \\
\text { Coastal Kuala Langsa }\end{array}$} & \multirow{2}{*}{$\begin{array}{l}\text { Nilai ideal berdasarkan } \\
\text { literatur / Ideal value } \\
\text { based on the literature }\end{array}$} & \multirow{2}{*}{$\begin{array}{c}\text { Referensi / } \\
\text { Reference }\end{array}$} \\
\hline & & Kisaran & Rata-rata & & \\
\hline $\begin{array}{l}\text { Suhu / } \\
\text { Temperature }\end{array}$ & ${ }^{\circ} \mathrm{C}$ & $25,5-35,6$ & $30,5 \pm 1,7$ & $\begin{array}{c}27-30 \\
25,3-34,6 \\
11-32\end{array}$ & $1,2,3$ \\
\hline $\begin{array}{l}\text { Salinitas / } \\
\text { Salinity }\end{array}$ & $\mathrm{ppt}$ & $25,9-34,0$ & $29,9 \pm 1,3$ & $\begin{array}{l}18-33 \\
24-30\end{array}$ & 3,5 \\
\hline $\begin{array}{l}\mathrm{pH} / \\
\text { Acidity }\end{array}$ & - & $7,0-9,2$ & $8,1 \pm 0,3$ & $7-9$ & 6 \\
\hline DO & $\mathrm{mg} / \mathrm{l}$ & $3,9-6,8$ & $5,5 \pm 0,5$ & $2-12$ & 4 \\
\hline $\begin{array}{l}\text { Arus / Current } \\
\text { velocity }\end{array}$ & $\mathrm{m} / \mathrm{s}$ & $0,1-0,9$ & $0,3 \pm 0,1$ & $0,1-0,9$ & 3 \\
\hline
\end{tabular}

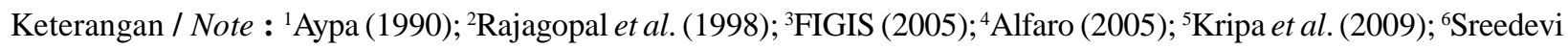
etal. (2014).

\section{Bahasan}

Penilaian terhadap kondisi ekologi perairan merupakan tahapan penting yang harus dilakukan untuk mendukung pengelolaan dan pemanfaatan perairan secara baik, termasuk untuk budidaya kerang hijau. Berdasarkan pengelompokkan analisis komponen utama menunjukkan seluruh parameter perairan hanya memperhatikan kategori kuat. Karakteristik PC1 menjelaskan 34,9\% yang dibangun dengan nilai muatan yang relatif besar yaitu berturut-turut parameter salinitas $(0,590)$, suhu $(0,452)$ dan plankton (0,095), sedangkan PC2 dapat menjelaskan 29,5\% dari total ragam yang dibangun oleh parameter oksigen terlarut $(0,574)$ dan salinitas $(0,035)$ (Tabel 3). Dalam hal ini, analisis komponen utama berfungsi sebagai sarana untuk mengidentifikasi parameter-parameter yang memiliki kontribusi terbesar terhadap variasi temporal dan spasial kualitas perairan Kuala Langsa untuk pengembangan budidaya kerang hijau.

Suhu rata-rata perairan Kuala Langsa berkisar 25,5 $35,6^{\circ} \mathrm{C}$ dengan rata-rata $30,5 \pm 1,7^{\circ} \mathrm{C}$. Suhu perairan tersebut sangat dipengaruhi oleh keadaan meteorologi seperti musim, curah hujan, penguapan, kelembapan udara, kecepatan angin, ketinggian dari permukaan laut, kedalaman dari badan air dan intensitas radiasi sinar matahari. Menurut Sinambela et al. (2008), tingginya suhu perairan pada musim kemarau dibandingkan dengan musim hujan berkaitan erat dengan besarnya intensitas cahaya yang masuk ke dalam perairan, sehingga akan menentukan 
derajat panas yaitu semakin banyak sinar matahari yang masuk ke dalam suatu perairan, semakin tinggi suhu perairan, namun semakin bertambahnya kedalaman akan menurunkan suhu perairan.

Nilai kisaran suhu pada perairan Kuala Langsa tergolong layak untuk mendukung kehidupan kerang hijau, beberapa penelitian menyebutkan suhu optimal untuk mendukung pertumbuhan kerang hijau adalah 27 $30^{\circ} \mathrm{C}$ (Aypa, 1990); 25,3 - 34,6 ${ }^{\circ} \mathrm{C}$ (Rajagopal et al., 1998). FIGIS (2005) menjelaskan kerang hijau dapat mentoleransi suhu $11^{\circ} \mathrm{C}$ hingga $32^{\circ} \mathrm{C}$. Suhu memiliki efek positif pada gametogenesis kerang dan berpengaruh pada proses pemijahan (Nair \& Appukuttan, 2003; Kripa et al., 2009). Cappenberg (2008) menyebutkan bahwa berdasarkan hasil penelitian di daerah tropis, kerang hijau akan mati dalam waktu 30 menit pada suhu $43^{\circ} \mathrm{C}$. Menurut Rajagopal et al. (2006), kerang hijau dapat mencapai kelangsungan hidup sebesar $50 \%$ pada suhu $10-35^{\circ} \mathrm{C}$ pada kondisi laboratorium. Suhu perairan berpengaruh terhadap beberapa fungsi fisiologis organisme seperti respirasi, metabolisme, pertumbuhan, reproduksi dan juga mempengaruhi ekskresi amonia (Rejeki, 2001).

Salinitas perairan Kuala Langsa berkisar 25,9 - 34,0 ppt dengan rata-rata 29,9 $\pm 1,3$ ppt. Menurut McGuire \& Stevely (2009), kerang hijau masih dapat hidup pada kisaran salinitas antara 15 - 45 ppt. Salinitas tinggi (24 hingga $30 \mathrm{ppt}$ ) meningkatkan laju filtrasi kerang hijau (Rajesh et al., 2001). FIGIS (2005) juga menjelaskan bahwa kerang hijau menunjukkan pertumbuhan yang baik pada habitat estuari dengan kisaran salinitas 18 - 33 ppt. Salinitas 24-30 ppt secara signifikan meningkatkan indeks kondisi kerang (Kripa et al., 2009). Salinitas dan tekanan osmosis berkolerasi secara positif, osmoregulasi berkaitan dengan pemanfaatan energinya dimana semakin besar kerja osmotik yang dilakukan maka semakin besar pula energi yang dibutuhkan oleh organisme (Yuwono, 2006). Tingkat osmoregulasi yang tinggi dapat menghambat pertumbuhan karena energi lebih banyak dihabiskan untuk aktivitas osmoregulasi dibandingkan untuk proses pertumbuhan (Rusdi \& Karim, 2006). Variasi salinitas pada perairan yang jauh dari pantai akan relatif kecil dibandingkan dengan variasi salinitas di dekat pantai, terutama jika terjadi pemasukan air sungai.

Derajat keasaman $(\mathrm{pH})$ air laut relatif konstan karena adanya penyangga dari hasil keseimbangan karbon dioksida, asam karbonat, karbonat dan bikarbonat yang disebut buffer. Nilai pH biasanya dipengaruhi oleh laju fotosintesa, buangan industri serta limbah rumah tangga (Sastrawijaya, 2000). Nilai pH perairan Kuala Langsa berkisar 7,0 - 9,2 dengan rata-rata 8,1 $\pm 0,3$. Menurut Sreedevi et al. (2014), pH yang masih dapat ditoleran kerang hijau berkisar $7-9$. Derajat keasaman $(\mathrm{pH})$ juga dapat mempengaruhi jenis dan susunan zat dalam lingkungan perairan dan tersedianya unsur hara serta toksisitas unsur renik (Yeanny, 2007). Setiap organisme membutuhkan kisaran $\mathrm{pH}$ yang optimum bagi perkembangannya, $\mathrm{pH}$ yang terlalu asam atau basa dapat dengan cepat merusak permukaan insang hingga menyebabkan kematian.

Oksigen terlarut (DO) di perairan Kuala Langsa tercatat berkisar 3,9 - 6,8 mg/l dengan rata-rata 5,5 \pm 0,5 mg/l. Konsentrasi oksigen terlarut di perairan Kuala Langsa cenderung bersifat fluktuasi secara harian dan musiman akibat terjadi pencampuran dan pergerakan massa air, aktivitas fotosintesis, respirasi dan limbah yang masuk ke badan air.. Konsentrasi DO yang masih dapat ditoleran kerang hijau berkisar $2-12 \mathrm{mg} / \mathrm{l}$ (Alfaro, 2005). Ketersediaan oksigen di perairan Kuala Langsa diduga dipengaruhi oleh berbagai faktor antara lain kelimpahan fitoplankton dan kandungan bahan organik. Sumber oksigen di perairan berasal dari difusi udara, fotosintesis fitoplankton dan tumbuhan air serta air hujan dan aliran permukaan.

Kecepatan arus perairan di Kuala Langsa cenderung bersifat fluktuatif pada pagi, siang dan sore, dimana kecepatan arus berkisar $0,1-0,9 \mathrm{~m} / \mathrm{s}$ dengan rata-rata 0,3 $\pm 0,1 \mathrm{~m} / \mathrm{s}$. Arus berfungsi untuk mengurangi polutan atau sisa metabolisme yang dihasilkan dari kegiatan budidaya. Arus juga mempunyai peranan dalam transportasi unsur hara sebagai sumber makanan, gerakan air akan membawa nutrien yang cukup dan dapat mencuci kotoran-kotoran hasil budidaya (Rejeki, 2001; Noor, 2014). Arus perairan merupakan faktor penting dalam budidaya kerang hijau karena dapat mempengaruhi laju fitrasi. Kerang hijau yang mendapatkan makanannya dengan menyaring air (filter feeder) membutuhkan arus yang sesuai karena berfungsi sebagai pembawa plankton sebagai makanan alaminya. Arus pada budidaya kerang hijau juga dibutuhkan sebagai sumber oksigen, mencuci kotoran pada kontruksi atau menghilangkan limbah maupun organisme penempel yang berada pada kontruksi budidaya. Kecepatan arus yang optimal untuk budidaya kerang hijau berkisar 0,1 hingga $0,9 \mathrm{~m} / \mathrm{s}$ (FIGIS, 2005).

Kelimpahan fitoplankton minimal di perairan Kuala Langsa sebesar $1,32 \times 10^{5} \mathrm{sel} / \mathrm{m}^{3}$ dimana kelimpahan maksimal sebesar $6,86 \times 10^{5} \mathrm{sel} / \mathrm{m}^{3}$, dengan kelimpahan ratarata sebesar 3,88 x $10^{5} \pm 1,08 \times 10^{5} \mathrm{sel} / \mathrm{m}^{3}$. Diversitas fitoplankton di perairan Kuala Langsa didominasi oleh Bacilariophyceae yaitu diatom jenis Skeletonema, sedangkan dari kelas dinoflagelata tidak menunjukkan dominasi tertentu. Bacilariophyceae merupakan kelas fitoplankton pada kelompok diatom yang paling melimpah di perairan diduga karena sifatnya yang kosmopolit di berbagai kondisi perairan dan merupakan kelompok fitoplankton yang penting dalam rantai makanan (Alfaro et al., 2003). Kelimpahan fitoplankton khususnya kelas 
diatom di perairan Kuala Langsa tergolong melimpah, hal ini diduga disebabkan oleh beberapa faktor antara lain kondisi angin, arus, proses upwelling, suhu perairan, salinitas, zat hara, kedalaman perairan dan proses pencampuran massa air yang dapat mendukung proses fotosintesis fitoplankton. Ketersediaan fitoplankton di perairan Kuala Langsa sangat berkaitan dengan ketersediaan sumber makanan bagi organisme yang memiliki trofik level yang lebih tinggi, selain itu berfungsi sebagai pakan alami dalam kegiatan budidaya kerang hijau.

Ketersediaan dan kelimpahan makanan kerang hijau yaitu fitoplankton di perairan Kuala Langsa sangat mendukung pengembangan budidaya kerang hijau di lokasi tersebut. Makanan bagi kerang hijau akan mempengaruhi pertumbuhan jaringan. Penyimpanan dan penggunaan makanan yang dapat mengubah rasio berat badan terhadap panjang cangkang. Menurut Helm et al. (2004) kebiasaan makan kerang dihubungkan dengan makanan alami di perairan dimana kerang tersebut hidup, dengan komponen nutrien yang penting bagi pertumbuhan. Peneliti lain menyebutkan laju filtrasi kerang dipengaruhi oleh ukuran partikel/sel, kepadatan dan kualitas plankton, ukuran kerang dan faktor lingkungan (Riisgard, 2001a), sedangkan faktor lingkungan yang mempengaruhi laju filtrasi antara lain oksigen terlarut, $\mathrm{pH}$, suhu, salinitas dan partikel tersuspensi serta klorofil a (Riisgard, 2001b). Faktor lingkungan merupakan parameter penting karena mempengaruhi kebutuhan dan asupan pakan, sehingga berpengaruh terhadap laju pertumbuhan kerang (Pattikawa \& Ferdinandus, 2009). Penelitian yang dilakukan oleh Suryono et al. (1999) menyebutkan bahwa mikroalga Skeletonema sp. merupakan jenis yang paling banyak diserap kerang hijau. Kecepatan filtrasi oleh kerang hijau pada semua ukuran terhadap Skeletonema sp. lebih tinggi dibandingkan terhadap Chlorella sp. (Praktikto, 2013).

Penelitian Sagita et al. (2016), menunjukkan bahwa benih (spat) kerang hijau yang dikumpulkan di perairan Kuala Langsa berukuran lebar cangkang antara 3,0 - 9,5 $\mathrm{mm}$ tergantung pada metode yang digunakan. Penggunaan metode longline lebih efektif dibandingkan metode stick. Produksi spat kerang hijau dengan metode longline di perairan Kuala Langsa mencapai 3713,50 $\pm 53,40 \mathrm{~g}$ dengan total spat yang terkumpul sebanyak $175,7 \pm 12,6$ individu per kolektor ukuran 2 meter dan panjang spat rata-rata $7,33 \pm 1,22 \mathrm{~mm}$. Produksi spat dengan metode stick sebesar $2613,25 \pm 28,80$ gr dengan total spat yang terkumpul sebanyak 86,25 $\pm 13,72$ individu per kolektor ukuran 2 meter, dengan panjang rata-rata $6,76 \pm 1,44 \mathrm{~mm}$.

Penelitian Sagita et al. (2017) mengenai budidaya kerang hijau di perairan Kuala Langsa dengan metode longline dan stick dengan kepadatan berbeda, berdasarkan analisis sidik ragam data Specific Growth Rate (SGR) dari panjang (SGR L) dan bobot (SGR W) menunjukkan bahwa semua perlakuan metode, kepadatan dan interaksi berbeda signifikan pada taraf uji $5 \%(\mathrm{P}<0,05)$, dimana perlakuan perlakuan yang paling optimal yaitu perlakuan metode longline dengan kepadatan 20 individu pe kantong 5,30 L diperoleh rata-rata SGR (L) sebesar 0,86 $\pm 0,01 \%$ /hari dan SGR $(W)$ sebesar $1,18 \pm 0,04 \%$ /hari dengan sintasan 92,50 $\pm 2,89 \%$.

Spesies yang sama pada lokasi yang berbeda memiliki pertumbuhan yang berbeda pula, karena adanya faktor dalam maupun faktor luar yang mempengaruhi pertumbuhan biota tersebut. Faktor dalam meliputi faktor yang sulit dikontrol seperti genetik, umur, parasit dan penyakit, sedangkan faktor luar yang utama mempengaruhi pertumbuhan seperti kualitas perairan dan ketersediaan makanan dari alam (Kripa et al., 2009). Ukuran cangkang kerang juga dipengaruhi oleh fluktuasi faktor lingkungan, sedangkan bentuk cangkang kerang lebih dipengaruhi oleh faktor genetik (Ramesha \& Thippeswamy, 2009). Peneliti Garen et al. (2004), menyebutkan bahwa pertumbuhan kerang khususnya pada cangkang dan jaringan dapat dipengaruhi oleh kepadatan populasi, faktor fisik, kimia maupun biologis dan habitat.

\section{KESIMPULAN}

Kondisi ekologi perairan musim hujan dan kemarau dapat mendukung pengembangan budidaya kerang hijau di Kuala Langsa, dimana suhu $25,5-35,6^{\circ} \mathrm{C}$ dengan ratarata $30,5 \pm 1,7^{\circ} \mathrm{C}$; salinitas $25,9-34,0 \mathrm{ppt}$ dengan rata-rata $29,9 \pm 1,3^{\circ} \mathrm{C} ; \mathrm{pH} 7,0-9,2$ dengan rata-rata $8,1 \pm 0,3$; oksigen terlarut 3,9-6,8 mg/l dengan rata-rata $5,5 \pm 0,5 \mathrm{mg} / \mathrm{l}$; kecepatan arus $0,1-0,9 \mathrm{~m} / \mathrm{s}$ dengan rata-rata $0,3 \pm 0,1 \mathrm{~m} /$ $\mathrm{s}$; serta kelimpahan fitoplankton berkisar $1,32 \times 10^{5} \mathrm{sel} / \mathrm{m}^{3}$ hingga $6,86 \times 10^{5} \mathrm{sel} / \mathrm{m}^{3}$ dengan rata-rata $3,88 \times 10^{5} \pm 1,08 \times$ $10^{5} \mathrm{sel} / \mathrm{m}^{3}$. PCA yang diaplikasikan pada seluruh data menghasilkan dua komponen utama, yaitu PC1 dan PC2 dengan nilai akar ciri (eigenvalue) sebesar 2,096 dan 1,770; dimana PC1 secara kumulatif dapat menjelaskan ragam seluruh data sebesar 34,9\% yang dibangun oleh parameter salinitas, suhu dan fitoplankton, sedangkan PC2 sebesar $64,4 \%$ yang dibangun oleh parameter oksigen terlarut dan salinitas.

\section{PERSANTUNAN}

Terima kasih disampaikan kepada Program Studi Pengelolaan Sumberdaya Pesisir dan Lautan, Departemen Manajemen Sumberdaya Perairan, Institut Pertanian Bogor, yang telah banyak membantu dalam proses administrasi selama penelitian, serta Dinas Kelautan, Perikanan dan Pertanian Kota Langsa yang telah membantu dalam pelaksanaan penelitian. 


\section{DAFTAR PUSTAKA}

Acosta, V., Glem, M.E., Natera, Y., Urbano, T., Himmelman, J.H., Rey-Mende, M. \& Lodeiron, C. (2009). Differential growth of the mussel Perna perna and Perna viridis (Bilvalvia : Mytilidae) in suspended culture in the Golfo de Cariaco, Venezuela. Journal World Aquaculture Society, 40, 226- 235.

Alfaro, A.C., Jeffs, A.G. \& Hooker, S.H. (2003). Spatial variability in reproductive behaviour of green-lipped mussel populations of Northern New Zealand. Molluscan Research, 23, 223-238.

Alfaro, A.C. (2005). Effect of water flow and oxygen concentration on early settlement of the New Zealand green-lipped mussel Perna canalicus. Aquaculture, 246, 285-294.

Aypa, S.M. (1990). Mussel culture : Regional Sea Farming Development and Demonstration Project (p. 210). Bangkok : National Inland Fisheries Institute, Kasetsart University.

Blakar, I.A. (1978). A simple water and plankton sampler. Freshwater Biology, 8 (6), 533 - 537.

[BPS] Badan Pusat Statistik Kota Langsa. (2015). Kecamatan Langsa Barat Dalam Angka (p. 66). Kota Langsa : Badan Pusat Statistik.

Butler, E.C.V., Blackburn, S.I., Clementson, A.A., Morgan, P.P., Parslow, J.S. \& Volkman, J.K. (2001). A survey strategy and environmental monitoring network for an estuary supporting finfish cage culture. ICES Journal of Marine Science, 58, 460 - 468.

Boyacioglu, H. (2006). Surface water quality assessment using factor analysis. Water SA, 32(3), 389-393.

Cappenberg, H.A.W. (2008). Beberapa aspek biologi kerang hijau Perna viridis L. 1758. Oseana, 28(1), 33 40.

Costa-Pierce, B. (2008). An ecosystem approach to marine aquaculture: a global review. In : Soto, D., AguilarManjarrez, J., \& Hishamunda, N. (eds.). Building an ecosystem approach to aquaculture. FAO Fisheries and Aquaculture Proceedings, 14, 81 - 155.

Ellis, J., Cummings, V., Hewitt, J., Thrush, S., \& Norkko, A. (2002). Determining effect of suspended sediment on condition of a suspension feeding bivalve (Atrina zelandica): results of a survey, a laboratory experiment and a field transplant experiment. Journal of Experimental Marine Biology and Ecology, 267, 147 - 174.
FAO. (2006). State of World Aquaculture. Rome : Food and Agricultural Organization.

Fuentes, A., Fernandez-Segovia, I. \& Escrichel Serra, J.A. (2009). Comparison of physico-chemical parameters and composition of mussel (Mytilus galloprovincialis) from different Spanish origins. Journal of Food Chemistry, 112, 295-302.

[FIGIS] Fisheries Global Information System. (2005). Species Fact Sheet: Perna viridis (Linnaeus, 1758)Mytilidae. Rome : FAO.

Garen, P., Robert, S. \& Bougrier, S. (2004). Comparison of growth of mussel, Mytilus edulis, on longline, pole and bottom culture sites in the Pertuis Breton, France. Aquaculture, 232, $511-524$.

Helm, M.M., Bourne, N. \& Lovatelli, A. (2004). Hatchery Culture of Bivalves : A Practical Manual (p. 25). Rome : FAO.

Iscen, C.F., Emiroglu, O., Ilhan, S., Arslan, N., Yilmaz, V. \& Ahiska, S. (2008). Application of multivariat statistical techniques in the asssessment of surface water quality in Uluabat Lake, Turkey. Environmental Monitoring Asssessment, 144, 269-276.

Kripa, V. \& Mohamed, K.S. (2008). Green mussel (Perna viridis) farming in India, technology diffusion process and socioeconomic impacts. Journal of World Aquaculture Society, 9, 612-613.

Kripa, V., Mohamed, K.S., Velayudhan, T.S., Joseph, M., Alloycious, P.S. \& Sharma, J. (2009). Comparison of growth and gonad development of farmed green mussel Perna viridis L. in three habitats. Journal of Marine Biological Association of India, 51, 199 - 204.

Laxmilatha, P. (2013). A review of the green mussel, Perna viridis fishery of South West Coast of India. International Journal of Marine Science, 3, 408 416.

McGuire, M. \& Stevely, J. (2009). Invasive species of Florida's coastal waters : the asian green mussel (Perna viridis). The Florida Sea Grant College Program with support from the National Oceanic and Atmospheric Administration. U.S. Department of Commerce.

Nair, R.M. \& Appukuttan, K.K. (2003). Effect of temperature on the development, growth, survival and settlement of green mussel Perna viridis (Linnaeus, 1758). Aquaculture Research, 34, 1037 - 1045. 
Noo, N.M. (2015). Prospek pengembangan usaha budidaya kerang hijau (Perna viridis) di Pulau Pasaran, Bandar Lampung. Aquasains, 3 (2), 239 - 246.

Pattikawa, J.A., \& Ferdinandus, E. (2009). Growth of Mangrove Cockle (Anadara antiquata) Cultured in Cage. Marine Research Indonesia, 34, 91 - 96.

Praktikto, I. (2013). Filtrasi kerang hijau (Perna viridis) terhadap mikroalga pada jenis dan konsentrasi berbeda. Buletin Oseanografi Marina, 2, 35 - 40.

Radiarta, I.N., Saputra, A. \& Ardi, I. (2011). Analisis spasial kelayakan lahan budidaya kerang hijau (Perna viridis) berdasarkan kondisi lingkungan di Kabupaten Cirebon, Jawa Barat. Jurnal Riset Akuakultur, 6 (2), 341 - 352.

Rajagopal, S., Venugopalan, VP., Nair, K.V.K., Van der Velve, G., Jenner, H.A. \& Den Hartog, C. (1998). Reproduction, growth rate and culture potential of the green mussel, Perna viridis (L.) in Edaiyur backwaters, east coast of India. Aquaculture, 162, 187-202.

Rajagopal, S., Venugopalan, V.P., Van Der Velde, G. \& Jenner, H.A. (2006). Greening of the coasts: a review of the Perna viridis success story. Aquatic Ecology, 40, 273 $-297$.

Rajesh, K.V., Mohamed, K.S., \& Kripa, V. (2001). Influence of algal cell concentration, salinity and body size on the filtration and ingestion rates of cultivable Indian bivalves. Indian Journal Marine Science, 30, 87 - 92.

Ramesha, M.M., \& Thippeswamy, S. (2009). Allometry condition index in the freshwater bivalve Parreysia corrugate (Muller) from river Kempuhole, India. Asia Fisheries Science, 22, $203-214$.

Rejeki, S. (2001). Pengantar Budidaya Perairan (p. 76). Semarang : Badan Penerbit Universitas Diponegoro.

Riisgard, H.U. (2001a). On measurement of filtration rate in bilvalve-the stony road to reliable data : review and interpretation data. Marine Ecology Progress Series, $221,275-291$.

Riisgard, H.U. (2001b). Inaccurate bilvalve clearance rate measurements : A reply. Marine Ecology Progress Series, 22, 307-309.

Rusdi, I. \& Karim, M.Y. (2006). Salinitas optimum bagi sintasan dan pertumbuhan kepiting bakau (Scylla paramamosain). Jurnal Sains \& Teknologi, 6(3), 149 -157 .
Sagita, A., Kurnia, R., Sulistiono. (2016). Potential production of green mussel spat (Perna viridis L.) collected with different method in coastal waters Kuala Langsa, Aceh. Proceeding International Conference on Integrated Coastal Management and Marine Biotechnology, November, $29-30^{\text {th }}$, Bogor, Indonesia, $74-80$.

Sagita, A., Kurnia, R., Sulistiono. (2017). Budidaya kerang hijau (Perna viridis L.) dengan metode dan kepadatan berbeda di perairan pesisir Kuala Langsa, Aceh. Jurnal Riset Akuakultur, 12 (1), 57 - 68.

Sallih, K. (2005). Mussel Farming in The State of Sarawak, Malaysia: a Feasibility Study. Malaysia : Final Project of Fisheries Training Programme The United Nation University.

Sastrawijaya, A.T. (2000). Pencemaran Lingkungan (p. 274). Jakarta : Rineka Cipta.

Shrestha, S. \& Kazama, F. (2007). Assessment of surface water quality using multivariate statistical techniques: A case study of the Fuji River Basin, Japan. Environmental Modelling \& Software, 22, $464-475$.

Shumway, S.E., Davis, C., Downey, R., Karney, R., Kraeuter, J., Parson, J. \& Wikfors, G. (2003). Shellfish aquaculture in praise of sustainable economies and environments. World Aquaculture, 34, 15 - 17.

Simeonov, V., Stratis, J.A., Samara, C., Zachariadis, G., Voutsa, D., Anthemidis, A., Sofonious, M. \& Kouitmtzis, T. (2003). Asssesment of the surface water quality in Northern Greece. Water Research, 37 (4), $119-124$.

Sinambela, W.T., Dani, I.E., Rusnadi \& Nugroho, J.T. (2008). Pengaruh aktivitas matahari pada variasi curah hujan di Indonesia. Jurnal Sains Dirgantara, 5(2), 149 -168 .

Soon, T.K. \& Ransangan, J. (2014). A review of feeding behavior, growth, reproduction and aquaculture site selection for green-lipped mussel, Perna viridis. Advances in Bioscience and Biotechnology, 5, 462 469.

Sreedevi, P.R., Uthayakumar, V., Jayakumar, R., Joseph, Kumar, D.S. \& Ramasubramanian, V. (2014). Comparative valuation of on-bottom and off bottom mussel (Perna viridis) culture as a small scale enterprise in Chettuva Estuary at Kerala India. World Journal of Fish and Marine Science, 6, 487 - 493. 
Suryono, C.A., Suryono \& Irwani. (1999). Kecepatan filtrasi berbagai ukuran kerang hijau Perna viridis terhadap beberapa jenis mikroalga. Ilmu Kelautan, 4, 196-201.

Valavanis, V. (2002). Geographic Information Systems in Oceanography and Fisheries (p. 189) . London : Taylor and Francis.
Yeanny, M.S. (2007). Keanekaragaman makrobenthos di muara sungai Belawan. Jurnal Biologi Sumatera, 2 (2), $37-41$.

Yuwono, E., Sukardi, P., Sulistyo, S. \& Khairunisah. (2006). Perubahan osmolalitas plasma ikan bandeng (Chanos chanos) sebagai respon terhadap aklimatisasi salinitas medium yang berbeda. Ichtyos, 6(1), 11 - 16 . 